\title{
Campuran Beton Tahan Terhadap Air Rob Dengan Bahan Tambah Fly Ash Dan Viscocrete 3115 ID
}

\author{
Ignatius Dinar Bagasriantoํ, Drajat Adi Satria ${ }^{2}$ \\ email: ${ }^{1}$ ignatius_dinar@yahoo.com \\ Program Studi Teknik Sipil, Fakultas Teknik, Universitas Katolik Soegijapranata \\ Jl. Pawiyatan Luhur IV/1, Bendan Dhuwur, Semarang 50234
}

\begin{abstract}
Abstrak
Dijaman globalisasi ini perkembangan penduduk yang semakin pesat berbanding lurus dengan kebutuhan tempat tinggal yang semakin meningkat. Ketersediaan lahan yang semakin sedikit, maka dari itu sering dijumpai pemukiman yang terletak di pesisir pantai. Pada umumnya material yang digunakan pada rumah yang terletak di pesisir terbuat dari struktur beton. Pada penelitian ini dilakukan penambahan fly ash dan viscocrete 3115 ID sebagai bahan tambah. Tujuan dari pengujian ini adalah untuk mengetahui nilai kuat tekan beton yang diberi bahan tambah fly ash dan viscocrete 3115 ID serta dilakukan perawatan menggunakan air rob. Fly ash sebagai bahan tambah pembuatan benda uji ditambahkan dengan kadar $0 \%, 4 \%, 5 \%, 6 \%$, dan $7 \%$ yang dibandingkan terhadap berat semen. Sedangkan Viscocrete 3115 ID ash sebagai bahan tambah pembuatan benda uji ditambahkan dengan kadar $0 \%$, dan $2 \%$ yang dibandingkan dengan berat semen. Benda uji yang dibuat tergolong dalam beton normal karena memiliki berat massa volume antara $2200-2500 \mathrm{~kg} / \mathrm{m}^{3}$, yaitu sebesar $2354,382 \mathrm{~kg} / \mathrm{m}^{3}$. Pengujian kuat tekan beton dilakukan di umur ke 7, 28, dan 56 hari yang dilakukan di Laboratorium Universitas Katolik Soegijapranata Semarang. Dari penelitian yang dilakukan diperoleh hasil untuk kuat tekan beton pada hari ke 56 untuk kadar 0\%, 4\%, 5\%, 6\%, dan 7\% berturut-

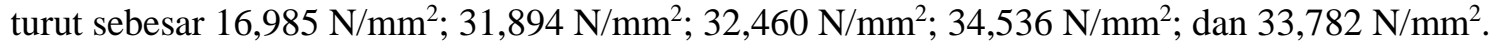

Kata kunci: Beton, Fly Ash, Viscocrete 3115 ID, kuat tekan beton, pengujian

\begin{abstract}
In the age of globalization, the rapid development of population is directly proportional to the increasing need for shelter. The availability of land is getting less, and therefore often found settlements located on the coast. In general, materials used in houses located on the coast are made of concrete structures. In this study the addition of fly ash and viscocrete 3115 ID was added as an additional material. The purpose of this test is to determine the compressive strength of concrete which is added with fly ash and viscocrete 3115 ID as well as treatment using rob water. Fly ash as an added ingredient in the manufacture of test specimens was added with levels of $0 \%, 4 \%, 5 \%, 6 \%$, and $7 \%$ compared to the weight of cement. Whereas Viscocrete 3115 ID ash as an added ingredient in the manufacture of test specimens was added with $0 \%$ content, and $2 \%$ compared to the weight of cement. The specimens made are classified as normal because they have a volume mass weight of $2200-2500 \mathrm{~kg} / \mathrm{m3}$, which is $2354.382 \mathrm{~kg} / \mathrm{m3}$. Concrete compressive strength testing was carried out at the age of 7, 28, and 56 days conducted at the Laboratory of Soegijapranata Catholic University Semarang. From the research conducted obtained results for concrete compressive strength on day 56 for levels of $0 \%, 4 \%, 5 \%, 6 \%$, and $7 \%$ respectively $16.985 \mathrm{~N} / \mathrm{mm} 2 ; 31,894 \mathrm{~N} / \mathrm{mm} 2$; $32,460 \mathrm{~N} / \mathrm{mm} 2 ; 34,536 \mathrm{~N} / \mathrm{mm} 2$; and 33,782 N/mm2.
\end{abstract}

Keywords: Concrete, Fly Ash, Viscocrete 3115 ID, concrete compressive strength, testing 


\section{PENDAHULUAN}

\subsection{Latar Belakang}

Pada umumnya material yang digunakan pada rumah yang terletak di pesisir terbuat dari struktur beton. Beton merupakan bagian struktur pada sebuah bangunan yang berfungsi untuk menahan beban bangunan tersebut. Pada daerah pesisir di Indonesia terdapat banyak area pemukiman yang sering terendam air rob. Fenomena banjir rob dipengaruhi oleh pasang surut air laut. Air rob yang berhubungan langsung dengan struktur beton dapat mengakibatkan kerusakan pada beton. Kerusakan pada beton disebabkan oleh banyaknya kandungan garam yang terdapat dalam air rob. Maka dari itu pada pembuatan campuran beton untuk infrastruktur yang terletak pada daerah pesisir biasanya ditambahkan zat adiktif yang berfungsi untuk menghambat sulfat yang berdampak buruk pada beton. Selain zat adiktif pada campuran beton juga dapat ditambahkan bahan tambah yang berfungsi untuk meningkatkan kinerja beton. Salah satu bahan tambah yang dapat digunakan adalah abu terbang (fly ash).

\subsection{Rumusan Masalah}

Rumusan masalah penelitian ini adalah seberapa besar nilai kuat tekan beton yang diberi bahan tambahan fly ash dan viscocrete 3115 ID dibandingkan terhadap beton normal dan dilakukan perawatan menggunakan air rob. Yang dimaksud dengan beton normal disini adalah beton yang dibuat dari materialmaterial dengan komposisi yang sesuai ketentuan SNI 7394 : 2008.

\subsection{Tujuan Penelitian}

Tujuan dari penelitian ini adalah untuk mengetahui nilai kuat tekan beton yang diberi bahan tambahan fly ash dan viscocrete 3115 ID dan membandingkan hasil nilai kuat tekan beton yang nantinya berguna untuk mengetahui kadar optimal penggunaan fly ash dan viscocrete 3115 ID sebagai bahan tambah dalam pembuatan beton.

\subsection{Manfaat Peneltian}

Adapun beberapa manfaat untuk dari hasil penelitian untuk perkembangan penelitian inovasi beton sebagai berikut:

a. Mendapatkan pengetahuan dari penelitian tentang pengaruh penambahan fly ash dan viscocrete 3115 ID terhadap kuat tekan beton pada campuran beton yang tahan terhadap air rob

b. Mendapatkan pengetahuan tentang komposisi perbandingan optimal penambahan fly ash dan viscocrete 3115 ID terhadap kuat tekan beton pada campuran beton yang tahan terhadap air rob.

\subsection{Batasan Penelitian}

Berikut merupakan batasan masalah untuk melakukan penelitian ini :

a. Material yang digunakan untuk membuat beton diantaranya :

a.1. Semen yang digunakan adalah semen Portland Composite Cement (PCC).

a.2. Air yang digunakan adalah air yang dapat diminum, dari sumber sumur dalam kampus Unika Soegijapranata.

a.3. Agregat halus berupa pasir Muntilan.

a.4. Agregat kasar berasal dari Magelang.

b. Cetakan yang digunakan untuk membuat beton adalah silinder kecil dengan diameter $15 \mathrm{~cm}$ dan tinggi $30 \mathrm{~cm}$ sejumlah 3 buah.

c. Bahan tambah untuk beton yaitu Fly Ash dan Viscocrete 3115 ID. 
d. Air yang digunakan untuk proses perawatan merupakan air rob yang berasal dari Jalan Yos Sudarso Semarang.

e. Pengujian kuat tekan beton dilakukan saat beton umur 7 hari, 28 hari, dan 56 hari.

f. Pengujian kuat tekan beton untuk silinder besar dilakukan di laboratorium Universitas Katolik Soegijapranata.

\section{METODE PENELITIAN}

\subsection{Uraian Umum}

Penelitian ini dilakukan melalui beberapa tahap untuk melakukan penelitian, yang diawali dengan persiapan dan diakhiri dengan penutup.

\subsection{Tahapan Penelitian}

Penelitian ini terdiri dari beberapa tahap sebagai berikut:

\subsubsection{Tahap I}

Tahap ini diawali dengan persiapan material dan diakhiri dengan perencanaan mix design. Berikut merupakan penjelasan dari masing-masing tahapan:

a. Studi Literatur

Studi Literatur yang digunakan sebagai penunjang pada penelitian ini berasal dari berbagai sumber, yaitu buku cetak maupun buku elektroik yang diunduh dari internet, jurnaljurnal, tugas akhir dan artikel-artikel pendukung yang masih berhubungan dengan judul tugas akhir. Literatur yang digunakan dalam penyusunan tugas akhir ini memiliki kaitan dengan beton, fly ash, dan viscocrete 3115 ID. b. Perencanaan Mix Design

Pada perencanaan mix design atau pencampuran komposisi material beton menggunakan peraturan SNI 7394-2008 sebagai acuan perencanaan mix design.

c. Pengadaan Material Material yang digunakan adalah pasir Muntilan (agregat halus), kerikil Magelang (agregat kasar), semen , air laboratorium Fakultas Teknik Universitas Katolik Soegijapranata, bahan tambah fly ash dan Viscocrete $3115 \mathrm{ID}$

d. Persiapan Benda Uji

Alat yang digunakan dalam penelitian ini adalah satu set mesin ayakan, satu set alat uji slump test, cetakan silinder, mesin concrete mixer, alat uji kuat tekan beton dan alat bantu lainnya.

\subsubsection{Tahap II}

Berikut merupakan tahapan yang diawali dari pembuatan benda uji dan tahap akhirnya merupakan pembahasan dari penelitian yang telah dilakukan.

a. Pengujian Material

Pengujian material yang dilakukan sebagai berikut:

a.1. Analisis Saringan Agregat

Pengujian analisis saringan agregat halus merujuk pada SNI 03-19681990. Uji dilakukan untuk menentukan pembagian gradasi butiran agregat halus dan modulus kehalusan agregat halus itu sendiri. Dengan adanya pengujian ini dapat diketahui tingkat gradasi pasir.

a.2. Analisa Berat Jenis dan
Penyerapan Agregat
Pengujian dilakukan dengan
mengacu SNI 1970:2008,
pengujian dilakukan untuk dapat

G-SMART Jurnal Teknik Sipil Unika Soegijapranata Semarang | ISSN : 2620-5297 (online) 
mengetahui dan menghitung selisih berat agregat halus dan berat air.

a.3. Analisa Kadar Air Agregat

Pengujian kadar air untuk agregat halus dan agregat kasar dilakukan berdasarkan SNI 03-1971-1990. Pengujian ini dilakukan dengan tujuan untuk mengetahui kandungan presentase kadar air pada agregat halus dan agregat kasar.

a.4. Pengujian Kadar Lumpur Agregat Halus

Pengujian dilakukan dengan mengacu SNI 2816:2014, tujuan dari pengujian ini adalah untuk mengetahui kandungan lumpur dan kotoran organis pada agregat halus.

b. Pembuatan Benda Uji

Pembuatan benda uji terdiri dari pembuatan campuran beton, uji slump, dan perawatan beton. Berikut merupakan langkah dari pembuatan tiga benda uji:

b.1. Siapkan semen sejumlah 5,5451 $\mathrm{kg}$

b.2. Siapkan agregat halus sejumlah $14,8179 \mathrm{~kg}$

b.3. Siapkan Agregat kasar sejumlah $18,8609 \quad \mathrm{~kg}$

b.4. Siapkan air bersih sejumlah $3,9873 \mathrm{~kg}$.

b.5. Agregat halus dan agregat kasar yang telah disiapkan dimasukan kedalam mesin molen (concrete mixer) dengan perbandingan yang telah direncanakan.

b.6. Kemudian masukan semen yang sudah disiapkan kedalam mesin molen (concrete mixer) yang telah berisi agregat halus dan agregat kasar b.7. Kemudian tambahkan fly ash yang telah disiapkan kedalam mesin molen (concrete mixer). Penambahan fly ash dilakukan pada variabel B seberat $221,8 \mathrm{gr}$, variabel C seberat 277,2 gr, variabel D seberat $332,7 \mathrm{gr}$, dan variabel E seberat 388,1 gr

b.8. Lalu masukan air sesuai takaran yang sudah disiapkan kedalam mesin molen (concrete mixer)

b.9. Kemudian masukan viscocrete 3115 ID seberat 110,9 gr kedalam mesin molen (concrete mixer) untuk variabel $\mathrm{B}$, variabel $\mathrm{C}$, variabel $\mathrm{D}$, dan variabel $\mathrm{E}$

b.10. Lalu jika proses pencampuran beton sudah selesai dan merata, kemudian dilanjutkan dengan melakukan slump test untuk dapat mengetahui tingkat kemudahan pengerjaan (workability) dan kekentalan pada beton tersebut

b.11. Jika proses slump test sudah selesai dilanjutkan dengan menuangkan hasil adukan campuran beton kedalam cetakan yang berbentuk silinder

b.12. Diamkan cetakan benda uji yang telah terisi beton segar tersebut selama \pm 24 jam dan letakkan di tempat yang tidak terkena sinar matahari

b.13. Setelah \pm 24 jam, cetakan beton dapat dibuka dan benda uji tersebut dimasukan kedalam bak perendam yang sudah berisi air rob untuk dilakukan proses perawatan beton (curing). 


\section{c. Perawatan Benda Uji}

Perawatan benda uji dilakukan pada benda uji sebelum dilakukan langkah pengujian kuat tekan beton. Perawatan benda uji (curing) berpedoman pada SNI 2847:2013. Pada proses perawatan benda uji (curing) menggunakan metode perendaman. Pada penelitian ini dilakukan perawatan (curing) dengan cara merendam benda uji dengan air rob dalam bak perendaman yang terletak di Laboratorium Bahan Bangunan Universitas Katolik Soegijapranata.

\section{d. Pengujian Benda Uji}

Tahap yang dilakukan setelah proses perawatan benda uji adalah dilakukan pengujian kuat tekan beton pada hari ke 7, 28 dan 56. Uji kuat tekan ini dilakukan di Laboratorium Bahan Bangunan Teknik Sipil Fakultas Teknik Universitas Katolik Soegijapranata.

\subsubsection{Tahap III}

Tahap ini merupakan proses pengolahan dan analisis data hasil penelitian yang telah dilakukan. Proses pengolahan dan analisis data dilakukan dengan membandingkan nilai uji kuat tekan dari masing-masing lima variabel jenis campuran benda uji.Setelah selesai melakukan pengolahan dan menganalisis data dari hasil penelitian lima variabel benda uji maka dapat ditarik kesimpulan dan saran berdasarkan pembahasan dari penelitian yang telah dilakukan.

\section{ANALISIS DATA DAN PEMBAHASAN}

\subsection{Hasil Pengujian Bahan}

Sebelum memulai perencanaan mix design dan membuat benda uji adalah melakukan pengujian material atau bahan penyusun beton. Pengujian yang dilakukan terhadap material yang digunakan bertujuan untuk mengetahui kualitas dari setiap bahan penyusun beton. Pengujian bahan dan pembuatan benda uji dilakukan di Laboratorium Bahan Bangunan Universitas Katolik Soegijapranata.

a. Analisis Saringan Agregat

Pada saat melakukan pengujian analisis saringan agregat berpedoman pada SNI 03-1968-1990

a.1. Analisis Saringan Agregat Halus Hasil pengujian analisisis saringan agregat halus dapat dilihat pada tabel sebagai berikut:

\begin{tabular}{|c|c|c|c|c|c|}
\hline $\begin{array}{c}\text { Ukuran } \\
\text { Ayakan }\end{array}$ & $\begin{array}{c}\text { Berat } \\
\text { Agregat } \\
\text { Tertahan }\end{array}$ & $\begin{array}{c}\text { Persentase } \\
\text { Agregat } \\
\text { Tertahan }\end{array}$ & $\begin{array}{c}\text { Tertahan } \\
\text { Kumulatif }\end{array}$ & $\begin{array}{c}\text { Lolos } \\
\text { Kumulatif }\end{array}$ & $\begin{array}{c}\text { Pasir Agak } \\
\text { Halus } \\
\text { SNI 03-2834- } \\
2000\end{array}$ \\
\cline { 1 - 3 }$(\mathrm{mm})$ & $(\mathrm{gram})$ & $(\%)$ & $(\%)$ & $(\%)$ & - \\
\hline- & 0,000 & 0,000 & 0,000 & 100,000 & $100-100$ \\
\hline 19 & 0,000 & 0,000 & 0,000 & 100,000 & $100-100$ \\
\hline 9,500 & 0,000 & 0,000 & 0,000 & 100,000 & $100-100$ \\
\hline 4,750 & 1,20 & 0,241 & 0,241 & 99,759 & 90.159 \\
\hline 2,360 & 22,80 & 4,575 & 4,815 & 95,185 & $85-100$ \\
\hline 1,180 & 50,90 & 10,213 & 15,028 & 84,972 & $75-100$ \\
\hline 0,600 & 118,70 & 23,816 & 38,844 & 61,156 & $60-79$ \\
\hline 0,300 & 125,60 & 25,201 & 64,045 & 35,955 & $12-40$ \\
\hline 0,150 & 130,10 & 26,104 & 90,148 & 9,852 & $0-10$ \\
\hline 0,075 & 34,40 & 6,902 & 97,051 & 2,949 & 0 \\
\hline Pan & 14,70 & 2,949 & 100,000 & 0,000 & - \\
\hline Total Berat & 498,400 & Modulus Kehalusan Butir $=4,10$ & \\
\hline
\end{tabular}

a.2. Analisis Saringan Agregat Kasar Hasil pengujian analisisis saringan agregat kasar dapat dilihat pada tabel sebagai berikut:

\begin{tabular}{|c|c|c|c|c|}
\hline Ukuran Ayakan & $\begin{array}{c}\text { Berat Agregat } \\
\text { Tertahan }\end{array}$ & $\begin{array}{c}\text { Persentase } \\
\text { Agregat Tertahan }\end{array}$ & $\begin{array}{c}\text { Tertahan } \\
\text { Kumulatif }\end{array}$ & $\begin{array}{c}\text { Lolos } \\
\text { Kumulatif }\end{array}$ \\
\hline (mm) & $($ gram) & $(\%)$ & $(\%)$ & $(\%)$ \\
\hline- & 0,00 & 0,00 & 0,00 & 100,00 \\
\hline 19 & 179,06 & 35,81 & 35,81 & 64,19 \\
\hline 9,500 & 304,16 & 60,83 & 96,65 & 3,35 \\
\hline 4,750 & 16,76 & 3,35 & 100,00 & 0,00 \\
\hline 2,360 & 0,00 & 0,00 & 100,00 & 0,00 \\
\hline 1,180 & 0,00 & 0,00 & 100,00 & 0,00 \\
\hline 0,600 & 0,00 & 0,00 & 100,00 & 0,00 \\
\hline 0,300 & 0,00 & 0,00 & 100,00 & 0,00 \\
\hline 0,150 & 0,00 & 0,00 & 100,00 & 0,00 \\
\hline 0,075 & 0,00 & 0,00 & 100,00 & 0,00 \\
\hline Pan & 0,00 & 0,00 & 100,00 & 0,00 \\
\hline Total Berat & 499,98 & \multicolumn{5}{|c|}{ Modulus Kehalusan Butir $=9,3246$} \\
\hline
\end{tabular}

b. Pengujian Kadar Lumpur Agregat Halus

Hasil pengujian kadar lumpur agregat halus bisa dilihat pada tabel sebagai berikut :

$$
\text { b.1. } \text { Pasir }+ \text { lumpur } \quad=132 \mathrm{ml}
$$




$$
\begin{array}{ll}
\text { b.2. Tinggi Pasir } & =126 \mathrm{ml} \\
\text { b.3. Tinggi lumpur } & =6 \mathrm{ml} \\
\text { b.4. Kandungan lumpur } & =\frac{\mathrm{b} .3 .}{\mathrm{b} .1 .} \times 100 \% \\
& =\frac{6}{132} \times 100 \% \\
& =4,545 \%
\end{array}
$$

Dari hasil pengujian didapatkan kandungan lumpur pada agregat halus sebesar $4,545 \%<5 \%$ yang menunjukkan bahwa agregat halus tidak perlu dicuci.

c. Pengujian Berat Volume

Pada pengujian analisis berat volume agregat halus berpedoman pada SNI 1973:2008.

c.1. Berat Volume Agregat Halus

$$
\begin{aligned}
& \text { a. Tinggi wadah } \quad=17,5 \mathrm{~cm} \\
& \text { Diameter wadah }=15 \mathrm{~cm} \\
& \text { Volume wadah } \\
& =\pi \times \mathrm{r}^{2} \times \mathrm{t} \\
& =3,14 \times\left(7,5^{2}\right) \times 17,5 \\
& =3090938 \mathrm{~cm}^{3} \\
& =3,090938 \text { liter } \\
& =
\end{aligned}
$$

c.2. Berat Volume Agregat Kasar

$$
\begin{aligned}
& \text { Tinggi wadah } \quad=17,5 \mathrm{~cm} \\
& \begin{aligned}
\text { Diameter wadah } & =15 \mathrm{~cm} \\
& =\pi \times \mathrm{r}^{2} \times \mathrm{t}
\end{aligned} \\
& \begin{aligned}
\text { Volume wadah } & =3,14 \times\left(7,5^{2}\right) \times 17,5 \\
= & 3090938 \mathrm{~cm}^{3} \\
= & 3,090938 \text { liter }
\end{aligned}
\end{aligned}
$$

b. Berat wadah $\quad=4,29 \mathrm{~kg}$

c. Berat wadah + agregat $=9,44 \mathrm{~kg}$

d. Berat agregat (c-b) $=9,44-4,29$

$$
=5,15 \mathrm{~kg}
$$

$$
\text { e. Berat volume (d/a) } \begin{aligned}
& =\frac{\mathrm{d}}{\mathrm{a}} \\
& =\frac{5,15}{3,090938} \\
= & 1,666 \mathrm{~kg} / \text { liter }
\end{aligned}
$$

d. Pengujian Kadar Air Agregat

Pada pengujian analisis kadar air agregat halus berpedoman pada SNI 03-1971:1990.

d.1. Kadar Air Agregat Halus
a. Berat wadah $\quad=70,4 \mathrm{gr}$
b. Berat wadah + agregat $=570,4$ gr
c. Berat agregat $(b-a)=570,4-70,4$ $=500 \mathrm{gr}$

d. Berat wadah + agregat kering

e. Berat agregat kering (d-a)

$$
=565,4 \mathrm{gr}
$$

$$
\begin{aligned}
& =565,4-70,4 \\
& =495 \mathrm{gr}
\end{aligned}
$$

f. Kadar air

$$
\begin{aligned}
& =\frac{\mathrm{c}-\mathrm{e}}{\mathrm{e}} \times 100 \% \\
& =\frac{500-495}{495} \times 100 \% \\
& =1,01 \%
\end{aligned}
$$

d.2. Kadar Air Agregat Kasar
a. Berat wadah
$=75,7 \mathrm{gr}$
b. Berat wadah + agregat $=575,7$ gr
c. Berat agregat (b-a) $=575,7-75,7$ $=500 \mathrm{gr}$
d. Berat wadah + agregat kering
e. Berat agregat kering (d-a) $=572,6 \mathrm{gr}$

$$
\begin{aligned}
& =572,6-75,7 \\
& =496,9 \mathrm{gr}
\end{aligned}
$$

e. Pengujian Berat Jenis

Pada pengujian analisis berat jenis agregat halus berpedoman pada SNI 1970:2008. 
e.1. Berat Jenis Agregat Halus

Hasil pengujian berat jenis agregat halus dapat dilihat pada tabel sebagai berikut:

\begin{tabular}{|l|c|}
\hline \multicolumn{1}{|c|}{ Keterangan } & Hasil Percobaan \\
\hline Apparent Specific. Gravity $\left(\mathrm{gr}^{\prime} \mathrm{cm}^{3}\right)$ & 2,688 \\
\hline Bulk Specific. Gravity Kondisi Kering $\left(\mathrm{gr}^{\mathrm{r}} \mathrm{cm}^{3}\right)$ & 1,927 \\
\hline Bulk Specific. Gravity Kondisi SSD $\left(\mathrm{gr}^{3} / \mathrm{cm}^{3}\right)$ & 2,210 \\
\hline \% Penyerapan Air & 14,155 \\
\hline
\end{tabular}

e.2. Berat Jenis Agregat Kasar

Hasil pengujian berat jenis agregat kasar dapat dilihat pada tabel sebagai berikut:

\begin{tabular}{|l|c|}
\hline \multicolumn{1}{|c|}{ Keterangan } & Hasil Percobaan \\
\hline Apparent Specific. Gravity $\left(\mathrm{gr} / \mathrm{cm}^{3}\right)$ & 2,871 \\
\hline Bulk Specific. Gravity Kondisi Kering $\left(\mathrm{gr} / \mathrm{cm}^{3}\right)$ & 2,445 \\
\hline Bulk Specific. Gravity Kondisi SSD $\left(\mathrm{gr}^{3} \mathrm{~cm}^{3}\right)$ & 2,593 \\
\hline \% Penyerapan Air & 6,067 \\
\hline
\end{tabular}

\subsection{Perhitungan Campuran Beton}

Pembuatan campuran beton dilakukan dengan mengacu SNI 7394 : 2008. Mutu beton yang direncanakan pada penelitian kali ini adalah $\mathrm{K} 150$. Untuk membuat $1 \mathrm{~m}^{3}$ beton dengan mutu beton $\mathrm{K}$ 150 memiliki perbandingan semen $299 \mathrm{~kg}$, pasir $799 \mathrm{~kg}$, kerikil $1017 \mathrm{~kg}$, air $215 \mathrm{~kg}$ dan water ratio 0,72. Dari hasil perhitungan mix design diatas berdasarkan SNI 7394 : 2008, maka dapat disimpulkan untuk membuat 3 benda uji untuk tiap kadar $(0 \%, 4 \%, 5 \%, 6 \%$, dan 7\%) dibutuhkan Semen 5,5451 Kg; Pasir $14,8179 \mathrm{Kg}$; Agregat Kasar 18,8609 Kg; dan Air 3,9873 Kg.

\subsection{Pembuatan Benda Uji}

Pembuatan benda uji dibagi menjadi 5 variabel, yaitu pembuatan variabel A : fly ash $0 \%$ dan viscocrete $0 \%$, variabel B : fly ash $4 \%$ dan viscocrete $2 \%$, variabel C : fly ash 5\% dan viscocrete $2 \%$, variabel D: fly ash 6\% dan viscocrete $2 \%$ dan variabel E: fly ash $7 \%$ dan viscocrete $2 \%$.

\subsection{Perawatan Benda Uji}

Perawatan benda uji (curing) berpedoman pada SNI 2847:2013. Pada proses perawatan benda uji (curing) menggunakan metode perendaman. Proses perendaman (curing) dilakukan selama 6 hari untuk pengujian benda uji pada umur 7 hari, proses perendaman (curing) dilakukan selama 27 hari untuk pengujian benda uji pada umur 28 hari dan proses perendaman (curing) dilakukan selama 55 hari untuk pengujian benda uji pada umur 56 hari. Pada penelitian ini dilakukan perawatan (curing) dengan cara merendam benda uji dengan air rob dalam bak perendaman yang terletak di Laboratorium Bahan Bangunan Universitas Katolik Soegijapranata.

\subsection{Pengujian Kuat Tekan Beton}

Tahap yang dilakukan setelah proses perawatan benda uji adalah dilakukan pengujian kuat tekan beton pada hari ke 7 , 28 dan 56. Uji kuat tekan pada sampel beton berguna untuk dapat mengetahui kemampuan dari sampel beton tersebut menahan gaya tekan. Kuat tekan beton adalah perbandingan beban terhadap luas penampang beton. Uji kuat tekan ini dilakukan di Laboratorium Bahan Bangunan Teknik Sipil Fakultas Teknik Universitas Katolik Soegijapranata.

\subsubsection{Berat Massa Volume Beton Benda Uji Silinder}

Benda uji pada umur 7 hari memiliki rata-rata berat massa sebesar $2371,447 \mathrm{~kg} / \mathrm{m}^{3}$, benda uji pada umur 28 hari memiliki rata-rata berat massa sebesar $2340,377 \mathrm{~kg} / \mathrm{m}^{3}$ dan benda uji pada umur 
56 hari memiliki rata-rata berat massa sebesar $2351,321 \mathrm{~kg} / \mathrm{m}^{3}$. Berdasarkan SNI 03-2847-2002 berat massa volume untuk benda uji yang dibuat termasuk dalam kategori beton normal. Hal ini dikarenakan beton normal memiliki berat antara 2200 $2500 \mathrm{~kg} / \mathrm{m}^{3}$.

\subsubsection{Hasil Pengujian Kuat Tekan Beton}

Nilai kuat tekan beton diperoleh dari mesin uji kuat tekan (compression testing machine). Uji kuat tekan pada beton berguna untuk mengetahui kemampuan dari benda uji dalam menahan gaya tekan. Pengujian dilakukan hingga mencapai kekuatan maksimum yang ditandai dengan keretakan pada benda uji. Berikut ini merupakan hasil pengujian kuat tekan:

\subsubsection{Umur beton 7 hari}

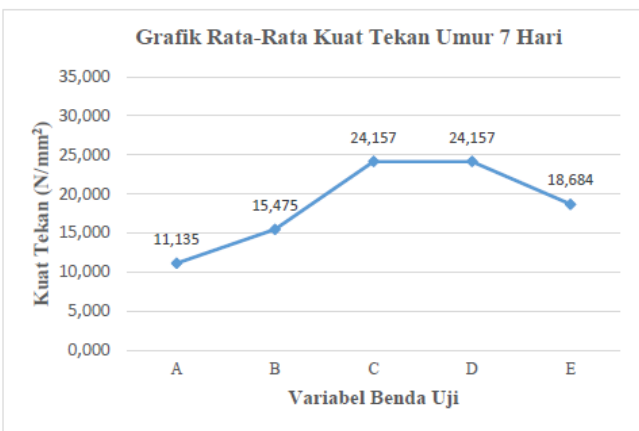

\subsubsection{Umur beton 28 hari}

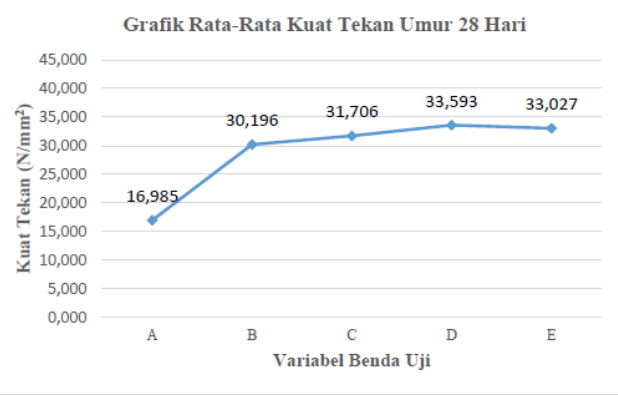

\subsubsection{Umur beton 56 hari}

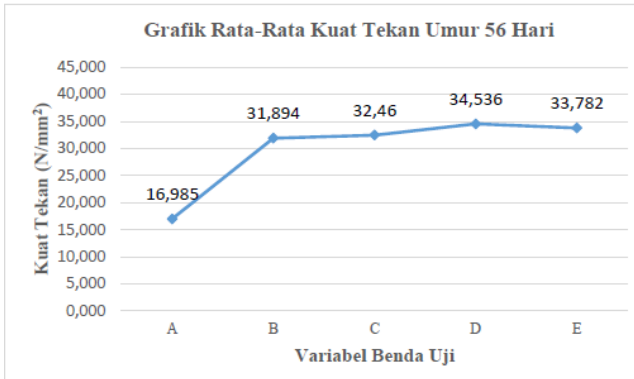

\subsubsection{Perkembangan Rata-rata Kuat Tekan}

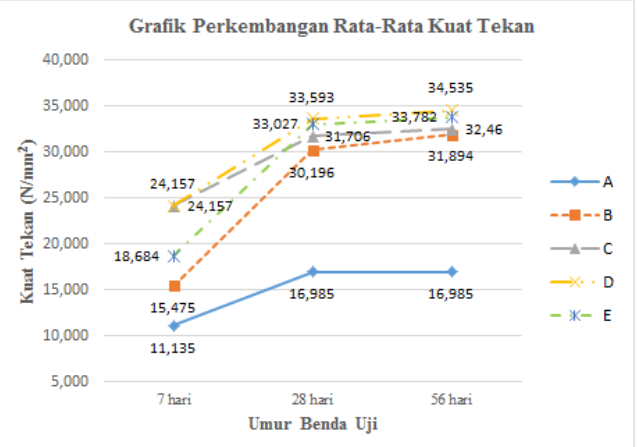

Terjadi penurunan rata-rata nilai kuat tekan pada variabel E (fly ash 7\% dan viscocrete $2 \%$ ) disebabkan karena kadar $\mathrm{SiO}_{2}$ (silika) yang banyak. $\mathrm{SiO}_{2}$ (silika) memiliki sifat menyerap air maka dari itu adukan beton akan lebih kental, yang bisa menyebabkan tidak ratanya penyebaran adukan beton pada saat proses pemasukan kedalam cetakan sehingga terdapat poripori yang tidak terisi. Adanya penurunan kuat tekan beton setelah penambahan suatu kadar tertentu dikarenakan sifat $\mathrm{SiO}_{2}$ (silika) yang menyerap air sehingga kandungan air didalam beton berkurang (Hapsari dkk, 2017).

\subsection{Pola Retak Pada Benda Uji Silinder}

Pengujian kuat tekan pada benda uji beton mengakibatkan terjadinya pola retak pada benda uji tersebut karena diberikan gaya tekan. Keruntuhan terjadi karena benda uji telah mencapai ketahanan 
maksimumnya dalam menahan gaya tekan. Pada pegujian kuat tekan yang dilakukan pola retak yang terjadi sebagian besar adalah retak geser. Pola retak geser memiliki bentuk retakan atau kehancuran berbentuk diagonal dari ujung atas hingga ujing bawah benda uji. Terdapat beberapa benda uji yang mengalami retak geser terbelah dan kerucut geser.

\section{PENUTUP}

\subsection{Kesimpulan}

Berdasarkan penelitian yang dilakukan dengan judul "Campuran Beton Tahan Terhadap Air Rob Dengan Bahan Tambah Fly Ash Dan Viscocrete 3115 ID" didapatkan kesimpulan sebagai berikut:

1. Dari pengujian kuat tekan benda uji yang dilakukan pada umur beton 7 hari, 28 hari dan 56 hari didapatkan hasil sebagai berikut:

\begin{tabular}{|c|c|c|c|c|c|}
\hline \multirow{2}{*}{ Variabel } & \multicolumn{2}{|c|}{ Kadar } & \multicolumn{3}{c|}{ Rata-Rata Nilai Kuat Tekan Beton (N/mm2) } \\
\cline { 2 - 6 } & $\begin{array}{c}\text { Fly Ash } \\
\text { (\%) }\end{array}$ & $\begin{array}{c}\text { Viscocrate } \mathbf{3 1 1 5} \\
\mathbf{( \% )}\end{array}$ & $\mathbf{7}$ hari & $\mathbf{2 8}$ hari & $\mathbf{5 6}$ hari \\
\hline A & 0 & 0 & 11,135 & 16,985 & 16,985 \\
\hline B & 4 & 2 & 15,475 & 30,196 & 31,894 \\
\hline D & 5 & 2 & 24,157 & 31,706 & 32,460 \\
\hline D & 6 & 2 & 24,157 & 33,593 & 34,536 \\
\hline E & 7 & 2 & 18,684 & 33,027 & 33,782 \\
\hline
\end{tabular}

Menurut hasil uji kuat tekan yang telah dilakukan menunjukan bahwa benda uji yang telah ditambahkan fly ash dan viscocrete 3115 ID dapat tahan terhadap air rob, hal itu ditunjukkan pada peningkatan nilai kuat tekannya

2. Melalui pengamatan pola retak pada benda uji yang telah dilakukan uji kuat tekan didapatkan retak yang terjadi adalah retak geser. Retak geser merupakan retak yang memiliki bentuk diagonal dari ujung atas hingga bawah. Retak geser terjadi akibat adanya gaya geser dan tidak adanya tulangan pada beton yang menahan gaya geser

3. Hasil pengujian kuat tekan pada benda uji menunjukkan bahwa variabel D ( fly ash 6\% dan viscocrete 2\%) baik digunakan sebagai bahan tambah pada beton yang berhubungan langsung dengan air rob.

\subsection{Saran}

Berdasarkan hasil penelitian yang telah dilakukan maka didapatkan beberapa saran yang dapat dilakukan untuk memperkuat hasil penelitian dengan hasil yang lebih akurat. Beberapa saran yang dapat diberikan:

1. Pada penelitian selanjutnya dapat dilakukan perawatan menggunakan air rob lebih lama agar perbedaan antara variabel benda uji dapat terlihat lebih jelas

2. Pada penelitian selanjutnya dapat dilakukan perawatan menggunakan air rob lebih lama agar perbedaan antara variabel benda uji dapat terlihat lebih jelas

3. Pada penelitian selanjutnya dapat dilakukan penambahan jumlah benda uji pada setiap variabel agar didapatkan hasil yang lebih akurat.

\section{DAFTAR PUSTAKA}

ACI Manual of Concrete Practice 1993 parts 1 226.3R-3 dalam Marthinus Adrian P, Marthin D. J. S, Reky S. W. 2015. Pengaruh Penambahan Abu Terbang (Fly Ash) Terhadap Kuat Tarik Belah Beton. Fakultas Teknik Jurusan Sipil Universitas Sam Ratulangi Manado. Jurnal Sipil Statik, Vol 3, No. 1, November 2015. https://media.neliti.com/media/pu blications/130642-ID-pengaruhpenambahan-abu-terbang-flyash.pdf 
Badan Standardisasi Nasional. 1990. SNI 03-1968-1990 Metode Pengujian Tentang Analisis Saringan Agregat Halus Dan Kasar. Jakarta: Badan Standardisasi Nasional. http://staffnew.uny.ac.id/upload/1 32256207/pendidikan/sni-031968-1990.pdf

Badan Standardisasi Nasional. 1990. SNI 03-1971-1990 Metode Pengujian Kadar Air Agregat. Bandung: Badan Standardisasi Nasional. http://www.ocw.upj.ac.id/files/Te xtbook-CIV-203-SNI-03-19711990-Kadar-Air.pdf

Badan Standardisasi Nasional. 1990. SNI 03-1974-1990 Metode Pengujian Kuat Tekan Beton. Bandung: Badan Standardisasi Nasional. https://www.academia.edu/128453 57/SNI_03-1974

1990_Metode_pengujian_kuat_tek an_beton

Badan Standardisasi Nasional. 2000. SNI 03-2834-2000 Tata Cara Pembuatan Rencana Campuran Beton Normal. Bandung: Badan Standardisasi Nasional. http://staffnew.uny.ac.id/upload/1 32256207/pendidikan/sni-032834-2000.pdf

Badan Standardisasi Nasional. 2002. SNI 03-2847-2002 Tata Cara Perhitungan Struktur Beton Untuk Bangunan Gedung. Bandung: Badan Standardisasi Nasional. http://tekniksipil.usu.ac.id/images/ PDF/2002-12-SNI-03-2847-2002Beton.pdf

Badan Standardisasi Nasional. 2004. SNI 15-2049-2004 Semen Portland.
Jakarta: Badan Standardisasi Nasional. http://staffnew.uny.ac.id/upload/1 32256207/pendidikan/sni-152049-2004.pdf

Badan Standardisasi Nasional. 2008. SNI 1970-2008 Cara Uji Berat Jenis Dan Penyerapan Air Agregat Halus. Jakarta: Badan Standardisasi Nasional. https://www.academia.edu/371206 66/Standar_Nasional_Indonesia_C ara_uji_berat_jenis_dan_penyerap an_air_agregat_kasar

Badan Standardisasi Nasional. 2008. SNI 1972 - 2008 Cara Uji Slump Beton. Bandung: Badan Standardisasi Nasional. http://staffnew.uny.ac.id/upload/1 32256207/pendidikan/sni-031972-1990.pdf

Badan Standardisasi Nasional. 2008. SNI 1973-2008 Cara Uji Berat Isi, Volume Produksi Campuran Dan Kadar Udara Beton. Jakarta: Badan Standardisasi Nasional. https://lauwtjunnji.weebly.com/up loads/1/0/1/7/10171621/sni-19732008_(cara_uji_berat_isi_volume _produksi_campuran_dan_kadar_ udara_beton).pdf

Badan Standardisasi Nasional. 2008. SNI 7394-2008 Tata Cara Perhitungan Harga Satuan Pekerjaan Beton Untuk Konstruksi Bangunan Gedung Dan Perumahan. Bandung: Badan Standardisasi Nasional. http://sutanto.blog.undip.ac.id/file s/SNI-7394-2008.pdf 
Badan Standardisasi Nasional. 2013. SNI 2847-2013 Persyaratan Beton Struktural Untuk Bangunan Gedung. Jakarta: Badan Standardisasi Nasional. http://staffnew.uny.ac.id/upload/1 32256207/pendidikan/sni-28472013.pdf

Badan Standardisasi Nasional. 2014. SNI 2816-2014 Metode Uji Bahan Organik Dalam Agregat Halus Untuk Beton. Jakarta: Badan Standardisasi Nasional. http://sni.litbang.pu.go.id/image/s ni/isi/sni-2816---2014.pdf

Danasi, M., \& Ade, L. 2015. Pengaruh Penambahan Fly Ash Pada Beton Mutu Tinggi Dengan Silica Fume Dan Filler Pasir Kwarsa. Program Studi Teknik Sipil Universitas Katolik Atma Jaya Yogyakarta. Komda VI BMPTISSI-Makasar, Oktober 2015. http://ft.uajy.ac.id/wpcontent/uploads/2015/12/Ade9.pdf

Departemen Pekerjaan Umum. 1990. SK SNI T-15-1990-03. Bandung: Yayasan LPMB. https://www.academia.edu/194987 77/SKSNI_T-15-199103_Tata_Cara_Perhitungan_Strukt ur_Beton_Untuk_Bangunan_Gedu ng

Ervianto, M., Saleh, F., \& Prayuda, H. 2016. Kuat Tekan Beton Mutu Tinggi Menggunakan Bahan Tambah Abu Terbang (Fly Ash) Dan Zat Adiktif (Bestmittel). Program Studi Teknik Sipil Fakultas Teknik Universitas Muhammadiyah Yogyakarta.
Sinergi, Vol. 20, No. 3, Oktober 2016: 199-206. doi: http://doi.org/10.22441/sinergi.20 16.3.005.

Hapasari, Sherli Pramudhita, Wibowo, \& Endah S. 2017. Kajian Pengaruh Variasi Komposisi Silica Fume Terhadap Parameter Beton Memadat Mandiri Dengan Kuat Tekan Beton Mutu Tinggi. Program Studi Teknik Sipil Fakultas Teknik Universitas Sebelas Maret Surakarta. E-Jurnal Matriks Teknik Sipil, Desember 2017.

https://103.23.224.239/matriks/arti cle/view/36924

Hidayat, Rizqi Rizaldi. 2011. Rancang Bangun Alat Pemisah Garam Dan Air Tawar Dengan Menggunakan Energi Matahari. Departemen Ilmu Dan Teknologi Kelautan Fakultas Perikanan Dan Ilmu Kelautan Institut Pertanian Bogor. Bogor. https://repository.ipb.ac.id/bitstrea $\mathrm{m} /$ handle/123456789/47134/C11rr h.pdf;jsessionid=703962D1F23FD 0F0BDCAB7F946D37E49?seque nce $=3$.

Hunggurami, E., Sudiyo, U., \& Amy, W. 2014. Pengaruh Masa Perawatan (Curing) Menggunakan Air Laut Terhadap Kuat Tekan Dan Absorpsi Beton. Jurusan Teknik Sipil Fakultas Sains Dan Teknik Universitas Nusa Cendana Kupang. Jurnal Teknik Sipil Vol. 03, No.2, September 2014. http://puslit2.petra.ac.id/ejournal/i ndex.php/jurnal-tekniksipil/article/view/19210. 
Peraturan Pemerintah. 1999. Peraturan Pemerintah No 18 Tahun 1999 Pengelolaan Limbah Berbahaya Dan Beracun. Presiden Republik Indonesia. http://hukum.unsrat.ac.id/pp/pp_1 8_99.htm

Pusat Bahasa Departemen Pendidikan Nasional. 2008. Kamus Besar Bahasa Indonesia. Departemen Pendidikan Nasional. Jakarta.

Sebayang, S., Widyawati, R., \& Habibie, M.B. 2012. Pengaruh Abu Terbang Terhadap Sifat-Sifat Mekanik Beton Alir Ringan Alwa. Jurusan Teknik Sipil Fakultas Teknik Universitas Lampung. Jurnal Teknik Sipil UBL, Vol. 03, No.1, April 2012. http://jurnal.ubl.ac.id/index.php/JT S/article/view/274/277.

Sutrisno, A., \& Widodo, S. 2012. Analisis Variasi Kandungan Semen Terhadap Kuat Tekan Beton Ringan Struktural Agregat Pumice. Program Studi Teknik Sipil Fakultas Teknik Universitas Negeri Yogyakarta. Jurnal Teknik Sipil.

https://eprints.uny.ac.id/10267/1/J URNAL\%20TEKNIK\%20SIPIL. pdf

Widhiarto, H., \& Sujatmiko, B. 2012. Analisis Campuran Beton Berpori Dengan Agregat Bergradasi Terpisah Ditinjau Terhadap Mutu Dan Biaya. Fakultas Teknik Universitas 17 Agustus 1945 Surabaya. Extrapolasi Jurnal Teknik Sipil Untag Surabaya, Vol. 05, No. 02, Hal 24-30. http://jurnal.untag-
sby.ac.id/index.php/EXTRAPOL ASI/article/view/817

Zardi, M., Rahmawati, C., \& Azman, T.K. 2016. Pengaruh Presentase Penambahan Sika Viscocrete 10 Terhadap Kuat Tekan Beton. Program Studi Teknik Sipil Fakultas Teknik Universitas Abulyatma Aceh. Jurnal Teknik Sipil Unaya, Vol. 02, No. 01. http://jurnal.abulyatama.ac.id/inde x.php/tekniksipilunaya/article/vie $\mathrm{w} / 18$ 